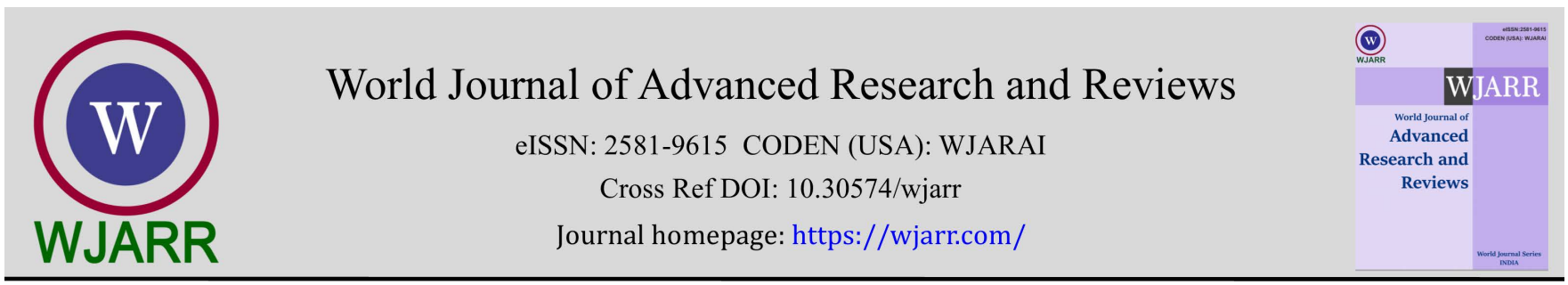

(RESEARCh ARTICLE)

Check for updates

\title{
Factors affecting can Tho university's brand value - approach from students
}

\author{
Nguyen Quoc Nghi *, Le Kim Thanh and Ngo Huynh Nhu \\ School of Economics, Can Tho University, Vietnam. \\ World Journal of Advanced Research and Reviews, 2021, 12(02), 190-196
}

Publication history: Received on 03 October 2021; revised on 07 November 2021; accepted on 09 November 2021

Article DOI: https://doi.org/10.30574/wjarr.2021.12.2.0583

\begin{abstract}
The study aims to identify factors influencing the brand value of Can Tho University. Research data were collected from 340 students studying at Can Tho University. By applying the exploratory factor analysis (EFA) and multivariate linear regression, the study has indicated factors putting positive impacts on Can Tho University's brand value. They are the university's reputation, training quality, graduate prospects, and alumni. In which, the training quality has the strongest influence on the brand value of the university.
\end{abstract}

Keywords: Reputation; Training quality; Brand value; Alumni

\section{Introduction}

The brand is a legal and intangible asset of a company (Maurya and Mishra, 2012) and is a logo of a company (Ivanovic and Collin, 2014). The brand helps reduce risks when customers buy a product or service (Assael, 1984). According to Kapferer (1994), the brand represents the identity system. The brand also creates intangible added value for the organization (Wolfe, 1993; Doyle and Stern, 2006) and builds the relationship with customers (Mckenna, 1991). The research by Sy and Phuong (2014) proved that branding in the university field helps learners distinguish one university from another, thereby supporting them make a good decision. As the competition among universities wakes up, domestic universities have to define their distinctive characteristics from international schools (Rekettye and Pozsgai, 2015). Beneke (2011) concluded that the university's branding activities raise students' awareness, improves its image and reputation.

Can Tho University was established in 1966 as the country's leading center for training, scientific research, and technology transfer. The university effectively trains and provides high-quality human resources for regional socioeconomic development. Also, it is the largest scientific research center in the Mekong Delta region of Vietnam. After more than 50 years of construction, Can Tho University was ranked 3rd on the ranking web of Vietnamese universities in 2018. Moreover, it is one of three Vietnamese universities that meet the international training standards to be a member of the ASEAN University Network (AUN), along with the National University of Hanoi and the National University of Ho Chi Minh City. This study is conducted to identify and improve positive affecting factors to the brand value of Can Tho University. The research results are an important scientific basis for the university leaders to build an appropriate action plan to improve their brand value.

\footnotetext{
${ }^{*}$ Corresponding author: Nguyen Quoc Nghi

School of Economics, Can Tho University, Vietnam.

Copyright $(2021$ Author(s) retain the copyright of this article. This article is published under the terms of the Creative Commons Attribution Liscense 4.0.
} 


\section{Theoretical framework and research hypotheses}

\subsection{Theoretical framework}

According to Erenkol and Duygum (2010), brand equity is one of the key concepts in marketing, it is considered one of the most valuable intangible assets for most companies. Parameswaran and Glowacka (1995) argued that each university needs a trustworthy brand that distinguishes it from others. University branding is essential, Hamid et al., (2012) said that the concept of university branding has not been fully developed and requires more research in this aspect. The university brand has special characteristics compared to other brand concepts. Accordingly, Bulotaite (2003) indicated that when it comes to the name of a university, it evokes associations, emotions, images, and appearances. According to Santovec (2007), a university brand is not only about a logo, a slogan, or a motto, but also the image in people's minds of that university.

\subsection{Research model}

According to Rivas and Domínguez (2017), reputation and prestige are two important criteria of a university's brand value in the current context. Studies by Agrey and Lampadan (2014) showed that the reputation of educational institutions positively affects learners' job opportunities. As presented by Overton-de Klerk and Sienaert (2016), a university's reputation is a significant component of the university's brand equity. Hence, the study proposes hypothesis H1: Reputation positively affects Can Tho University's brand value.

Akareem and Hossain (2016) proved that the training quality is a key factor in creating the school's brand image. In order to survive and develop, universities need to focus on the quality of training to improve student satisfaction and affirm the school's brand in the education industry. Dung et al., (2015) pointed out that the training quality impacts graduates' capacity and skills as well as the brand value of the educational institution. Therefore, the study sets the hypothesis H2: Training quality positively influences Can Tho University's brand value.

According to Thoai (2013), Agrey and Lampadan (2014), the job prospect plays an important role in students' choice of university. Luan (2015) confirmed that the university should improve students' graduate prospects, thereby enhancing the school's brand. From the perspective of Quy (2010), the training quality and reputation will be enhanced if graduates are recruited by foreign companies and multinational corporations. Thus, the authors suggest hypothesis H3: Graduate prospect positively affects the brand value of Can Tho University.

Bae et al., (2016) have said that there is a strong relationship between university brand identity and alumni support. According to Rauschnabel et al., (2016), alumni have a positive impact on a university's brand equity. In a research in 2006, McAlexander et al. have demonstrated that loyal alumni play an essential role in financial support and in building a strong university brand. The study proposes hypothesis H4 as follows: Alumni positively influence Can Tho University's brand value.

Based on the above literature review and research hypotheses, the research model of factors affecting the brand value of Can Tho University (CTU) is suggested below.

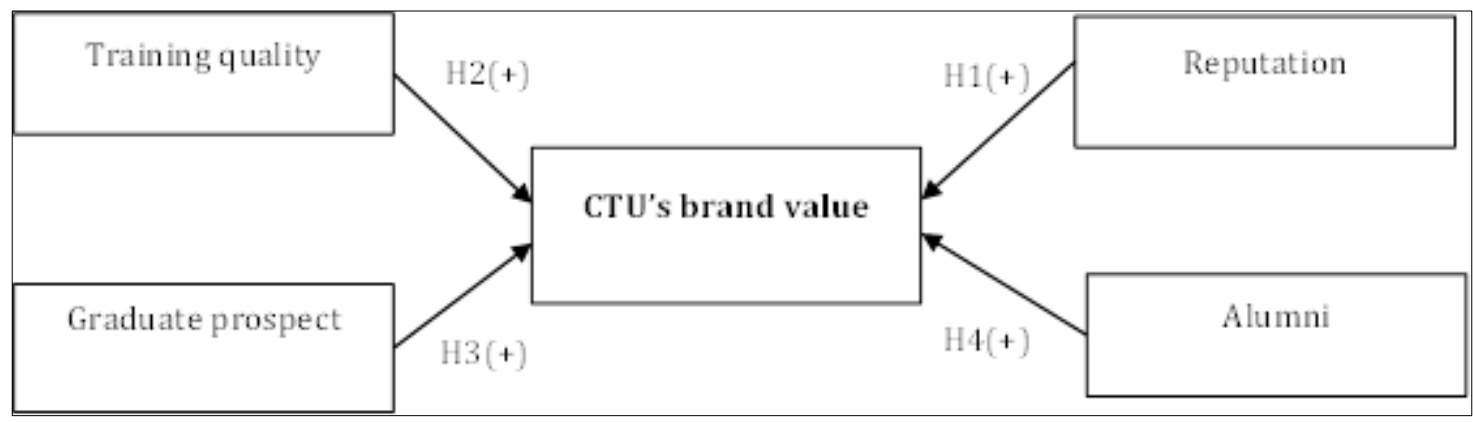

Figure 1 Proposed research model 
Table 1 Interpretation of observed variables in the research model

\begin{tabular}{|c|c|c|c|c|}
\hline Factor & Observed variable & Sign & Scale & Reference resources \\
\hline \multirow{4}{*}{$\begin{array}{l}\text { Reputation } \\
\text { (REP) }\end{array}$} & CTU has a long history. & REP1 & Likert 1-5 & \multirow{4}{*}{$\begin{array}{l}\text { Rivas and Domínguez } \\
\text { (2017), Agrey and } \\
\text { Lampadan (2014) } \\
\text { Overton-de Klerk and } \\
\text { Sienaert (2016) }\end{array}$} \\
\hline & CTU always has a good reputation and image. & REP2 & Likert 1-5 & \\
\hline & CTU's graduate output is high-quality. & REP3 & Likert 1-5 & \\
\hline & $\begin{array}{l}\text { CTU is a good brand for qualified human } \\
\text { resources training in Vietnam. }\end{array}$ & REP4 & Likert 1-5 & \\
\hline \multirow{4}{*}{$\begin{array}{l}\text { Graduate } \\
\text { prospect } \\
\text { (PRO) }\end{array}$} & CTU's graduates have high job opportunities. & PR01 & Likert 1-5 & \multirow{4}{*}{$\begin{array}{l}\text { Thoai (2013), Agrey and } \\
\text { Lampadan (2014), Luan } \\
\text { (2015) }\end{array}$} \\
\hline & CTU's graduates have high job adaptability. & PRO2 & Likert 1-5 & \\
\hline & Recruiters highly appreciate CTU's graduates. & PRO3 & Likert 1-5 & \\
\hline & $\begin{array}{l}\text { CTU's graduates have high opportunities to } \\
\text { get job promotion and development. }\end{array}$ & PRO4 & Likert 1-5 & \\
\hline \multirow{5}{*}{$\begin{array}{l}\text { Training } \\
\text { quality (QUA) }\end{array}$} & CTU's facilities are good. & QUA1 & Likert 1-5 & \multirow{5}{*}{$\begin{array}{l}\text { Akareem and Hossain } \\
(2016) \text {, Dung et al } \\
(2015)\end{array}$} \\
\hline & $\begin{array}{l}\text { CTU's lecturers are well-qualified and } \\
\text { enthusiastic. }\end{array}$ & QUA2 & Likert 1-5 & \\
\hline & $\begin{array}{l}\text { CTU's staff is caring and sympathetic to the } \\
\text { difficulties of students. }\end{array}$ & QUA3 & Likert 1-5 & \\
\hline & $\begin{array}{l}\text { CTU has innovative assessment and } \\
\text { encouragement for students. }\end{array}$ & QUA4 & Likert 1-5 & \\
\hline & $\begin{array}{l}\text { CTU's extracurricular activities are well } \\
\text { organized and helpful. }\end{array}$ & QUA5 & Likert 1-5 & \\
\hline \multirow[t]{4}{*}{ Alumni (ALU) } & Alumni actively support CTU. & ALU1 & Likert 1-5 & \multirow{4}{*}{$\begin{array}{l}\text { McAlexander et al } \\
(2006), \text { Bae et al. } \\
(2016), \text { Rauschnabel et } \\
\text { al., (2016) }\end{array}$} \\
\hline & $\begin{array}{l}\text { CTU alumni always commit to the university's } \\
\text { name and brand. }\end{array}$ & ALU2 & Likert 1-5 & \\
\hline & CTU alumni are successful in their careers. & ALU3 & Likert 1-5 & \\
\hline & $\begin{array}{l}\text { The success of CTU alumni reflects its high } \\
\text { quality of training. }\end{array}$ & ALU4 & Likert 1-5 & \\
\hline \multirow{5}{*}{$\begin{array}{l}\text { Brand value } \\
\text { (BV) }\end{array}$} & CTU is highly evaluated in the training quality. & BV1 & Likert 1-5 & \multirow{5}{*}{$\begin{array}{l}\text { Bulotaite (2003) } \\
\text { Santovec (2007), Hamid } \\
\text { et al. (2012). }\end{array}$} \\
\hline & CTU students are the first choice of recruiters. & BV2 & Likert 1-5 & \\
\hline & $\begin{array}{l}\text { CTU is the first choice of students in the } \\
\text { Mekong Delta and Vietnam. }\end{array}$ & BV3 & Likert 1-5 & \\
\hline & $\begin{array}{l}\text { CTU is the top brand in Vietnam and } \\
\text { Southeast Asia. }\end{array}$ & BV4 & Likert 1-5 & \\
\hline & $\begin{array}{l}\text { CTU is a famous brand that is not confused } \\
\text { with other brands. }\end{array}$ & BV5 & Likert 1-5 & \\
\hline
\end{tabular}

\section{Methodology}

\subsection{Analytical method}

The quantitative analyses used to test research hypotheses include the reliability test by Cronbach's Alpha, exploratory factor analysis (EFA), and multivariate linear regression. The process is carried out in the following order. Step 1: Using Cronbach's alpha to test the correlation among observed variables. Step 2: Using exploratory factor analysis (EFA) to 
test the convergent and discriminant validity of the observed variables. Step 3: Using multivariate linear regression to test research hypotheses.

\subsection{Data collection method}

The study applied convenient sampling to survey 340 students studying Natural Sciences, Technology, Environment, Agriculture, Fisheries, Social Sciences, Education, Political Science, Economics, and Law. According to Hair et al. (1998), to use the EFA, the ratio of observations and the measurement variable should be $5: 1$. This means one measurement variable requires a minimum of five observations. Tabachnick and Fidell (2007) concluded that the ideal sample size for regression analysis is $\mathrm{N} \geq 50+5^{*} \mathrm{~m}$, where $\mathrm{m}$ is the number of independent variables. Therefore, the sample size meets the reliability requirement for testing research hypotheses.

\section{Results and discussions}

\subsection{Scale reliability test}

Cronbach's alpha coefficient is used to eliminate "garbage" variables. Those with corrected item-total correlation values less than 0.3 will be rejected (Nunnally, 1978; Peterson, 1994; Slater, 1995). The scale is satisfactory if its Cronbach's alpha is greater than 0.6 (Nunnally and Bernstein, 1994). Table 2 shows that the corrected item-total correlation coefficient of each variable is satisfactory (the lowest is 0.507) and all scales have high Cronbach's alpha values (the smallest is 0.829). Hence, all variables are used in the further exploratory factor analysis (EFA).

Table 2 Results of the reliability test of scale

\begin{tabular}{|l|c|c|c|}
\hline \multicolumn{1}{|c|}{ Factor } & $\begin{array}{c}\text { Number of observed } \\
\text { variables }\end{array}$ & $\begin{array}{c}\text { Cronbach's } \\
\text { alpha }\end{array}$ & $\begin{array}{c}\text { Min corrected item- } \\
\text { total correlation }\end{array}$ \\
\hline Reputation & 4 & 0.802 & 0.507 \\
\hline Training quality & 5 & 0.819 & 0.562 \\
\hline Graduate prospect & 4 & 0.802 & 0.561 \\
\hline Alumni & 4 & 0.785 & 0.528 \\
\hline Brand value & 5 & 0.829 & 0.547 \\
\hline
\end{tabular}

\subsection{Exploratory factor analysis (EFA)}

Exploratory factor analysis (EFA) tests the convergent and discriminant validity of observed variables. In this study, EFA is carried out twice, for independent variables (reputation, graduate prospect, training quality, alumni) and the dependent variable (brand value). The first EFA result is ensured as follows: Significance level Sig. $=0.00 \leq 0.05$; KMO $=0.865$ (in the range of 0.5 and 1); factor loading of observed variables are greater than 0.5 ; total variance explained reaches $60.15 \%>50 \%$. This shows that the research data is satisfactory (Anderson and Gerbing, 1988). This result creates four factors, namely F1, F2, F3, F4. Observed variables remain in the same factors as proposed, so there is no change in factor names. Similarly, the result of EFA for the dependent variable gives the following values: Sig. is less than $0.05 ; 0 \leq \mathrm{KMO}=0.793 \leq 1$, factor loading values of variables are greater than 0.5 ; total variance extracted reaches $59.62 \%>50 \%$. This proves that the research data is consistent (Anderson and Gerbing, 1988). As a result, the analysis creates one factor F5 named Brand value.

Table 3 Factors formed from the EFA result

\begin{tabular}{|c|l|c|}
\hline Sign & \multicolumn{1}{|c|}{ Observed variable } & Factor \\
\hline F1 & 4 variables: REP1, REP2, REP3, REP4 & Reputation \\
\hline F2 & 5 variables: QUA1 QUA2, QUA3, QUA4, QUA5 & Training quality \\
\hline F3 & 4 variables: PR01, PR02, PR03, PR04 & Graduate prospect \\
\hline F4 & 4 variables: ALU1, ALU2, ALU3, ALU4 & Alumni \\
\hline F5 & 5 variables: BV1, BV2, BV3, BV4, BV5 & Brand value \\
\hline
\end{tabular}




\subsection{Multivariate linear regression}

Multivariate linear regression is applied to test research hypotheses. After the EFA step, multivariate linear regression determines factors affecting Can Tho University's brand value. The result is in table 4.

Table 4 Multivariate linear regression result

\begin{tabular}{|l|c|c|c|}
\hline Factor & Standardized coefficients & Sig. & Variance inflation factor (VIF) \\
\hline Reputation & 0.365 & 0.000 & 1.000 \\
\hline Training quality & 0.376 & 0.000 & 1.000 \\
\hline Graduate prospect & 0.342 & 0.000 & 1.000 \\
\hline Alumni & 0.318 & 0.000 & 1.000 \\
\hline Adjusted R $\mathrm{R}^{2}$ & & & $48.6 \%$ \\
\hline Durbin-Watson stat & & & 1.983 \\
\hline Sig. ANOVA & & & 0.000 \\
\hline
\end{tabular}

Based on table 4, the adjusted R2 value reaches $48.6 \%$ which proves that the brand value of Can Tho University is wellexplained by the factors in the model. The Sig.F value of the model is much smaller than the significance level $\alpha=5 \%$, so the established regression model is significant. Durbin-Watson $=1,983$ and VIF $<4$ showing that there is no autocorrelation and multicollinearity. Based on the result, all independent variables are statistically significant at the level of $1 \%$ and positively impact the brand value of Can Tho University. This reveals that the university's reputation, training quality, graduate prospects, and alumni have a positive influence on its brand value. In other words, if the reputation and training quality improves, students have high graduate prospects, and alumni have a good image, the brand value of Can Tho University will be enhanced.

\section{Conclusion}

To conclude, the study has identified four factors that positively affect the brand value of Can Tho University, which are reputation, training quality, graduate prospects, and alumni. In particular, the quality of training has the strongest influence on the brand value of Can Tho University. Based on the research results, the study proposes several governance implications to enhance the university's brand equity. Firstly, constantly improving the training quality. Secondly, building the university's image, reputation, and prestige. Thirdly, strengthen job prospects of graduates. Fourthly, promote the pioneering role of the alumni.

\section{Compliance with ethical standards}

\section{Acknowledgments}

The researchers appreciated all the corrections suggested and recommended by the experts.

\section{Disclosure of conflict of interest}

The authors declare that there are no competing or potential conflicts of interest.

\section{Statement of informed consent}

Informed consent was obtained from all individual participants included in the study.

\section{References}

[1] Agrey L, Lampadan N. Determinant factors contributing to student choice in selecting a university. Journal of Education and Human Development. 2014; 3(2): 391-404. 
[2] Akareem HS, Hossain SS. Determinants of education quality: what makes students' perception different?. Open review of educational research. 2016; 3(1): 52-67.

[3] Anderson JC, Gerbing DW. Structural equation modeling in practice: A review and recommended two-step approach. Psychological Bulletin. 1988; 103(3): 411-423.

[4] Assael H. Consumer behavior and marketing action. Kent Pub. Co. 1984.

[5] Bae YH, Hough M, Jung SU. Assessing the link between a public university's brand-building activities and alumni gift-giving. The Marketing Management Journal. 2016; 26(2): 144-158.

[6] Beneke JH. Marketing the institution to prospective students - A review of brand (reputation) management in higher education. International Journal of Business and Management. 2011; 6(1): 29.

[7] Bulotaite N. University heritage - an institutional tool for branding and marketing. Higher Education in Europe. 2003; 28(4): 449-454.

[8] Doyle P, Stern P. Marketing management and strategy. Pearson Education. 2006.

[9] Dung LT, Ha PV, Nam CH. Training quality of university education in economics and business sector in Vietnam: from an enterprise perspective. International seminar "Vietnam's economic integration: Opportunities and challenges. 2015.

[10] Erenkol AD, Duygun A. Customers perceived brand equity and a research on the customers of Bellona which is a Turkish furniture brand. The Journal of American Academy of Business. 2010; 16(1): 93-109.

[11] Hair JF, Tatham RL, Anderson RE, Black WC. Multivariate Data Analysis (5th ed.). New Jersey: Prentice-Hall. 1998.

[12] Hamid M, Rasool S, Kiyani AA, Ali F. Factors affecting the brand recognition: An exploratory study. Global Journal of Management and Business Research. 2012; 12(7): 75-82.

[13] Ivanovic A, Collin P. Dictionary of Marketing: Over 6,000 terms clearly defined. Bloomsbury Publishing. 2014.

[14] Kapferer JN. Strategic brand management: New approaches to creating and evaluating brand equity. Simon and Schuster. 1994.

[15] Luan ND. The linkage between universities and enterprises in human resources training for socio-economic development in Vietnam: Current situation and recommendations. Development and Integration Journal. 2015; 22(32): 82-87.

[16] Maurya UK, Mishra P. What is a brand? A Perspective on Brand Meaning. European Journal of Business and Management. 2012; 4(3): 122-133.

[17] McAlexander JH, Koenig HF, Schouten JW. Building relationships of brand community in higher education: A strategic framework for university advancement. International Journal of Educational Advancement. 2006; 6(2): 107-118.

[18] McKenna R. Marketing is everything. Harvard Business Review, January-February. 1991; 65-79.

[19] Nunnally J. Psychometric Theory. New York: McGraw-Hill. 1978.

[20] Nunnally JC, Bernstein IH. Psychometric theory (3rd ed.). New York, NY: McGraw-Hill. 1994.

[21] Overton-de Klerk N, Sienaert M. From research excellence to brand relevance: A model for higher education reputation building. South African Journal of Science. 2016; 112(5-6): 1-8.

[22] Parameswaran R, Glowacka AE. University image: An information processing perspective. Journal of Marketing for HIGHER EDUCATION. 1995; 6(2): 41-56.

[23] Peterson RA. A meta-analysis of Cronbach's coefficient alpha. Journal of consumer research. 1994; 21(2): 381391.

[24] Quy NH. Application of the balanced scorecard to university administration. Journal of Science and Technology University of Da Nang. 2010; 2(37): 116-123.

[25] Rauschnabel PA, Krey N, Babin BJ, Ivens BS. Brand management in higher education: the university brand personality scale. Journal of Business Research. 2016; 69(8): 3077-3086.

[26] Rekettye G, Pozsgai G. University and place branding: The case of universities located in ECC (European Capital of Culture) cities. Ekonomski vjesnik: Review of Contemporary Entrepreneurship, Business, and Economic Issues. 2015; 28(S): 13-24. 
[27] Rivas LA, Domínguez AK. Importancia y valor económico de la marca en el sistema universitario. Opción: Revista de Ciencias Humanas y Sociales. 2017; (83): 545-571.

[28] Santovec ML. How three colleges benefited from branding. Recruitment and Retention in Higher Education. 2017; 21(5): 8-8.

[29] Slater SF. Issues in conducting marketing strategy research. Journal of Strategic Marketing. 1995; 3(4): 257-270.

[30] Sy TNT, Phuong TNT. Branding in higher education: Theory and research model. Development and Integration Journal. 2014; 15(25): 81-86.

[31] Tabachnick BG, Fidell LS. Experimental designs using ANOVA (p.724). Belmont, CA: Thomson/Brooks/Cole. 2007.

[32] Thoai TQ. Solutions for attracting more applicants to Vietnam Forestry University. Vietnam National University of Forest Journal. 2013; 4: 128-137.

[33] Wolfe A. Profit from strategic marketing: How to succeed in business markets. Financial Times, Pitman Pub. 1993. 